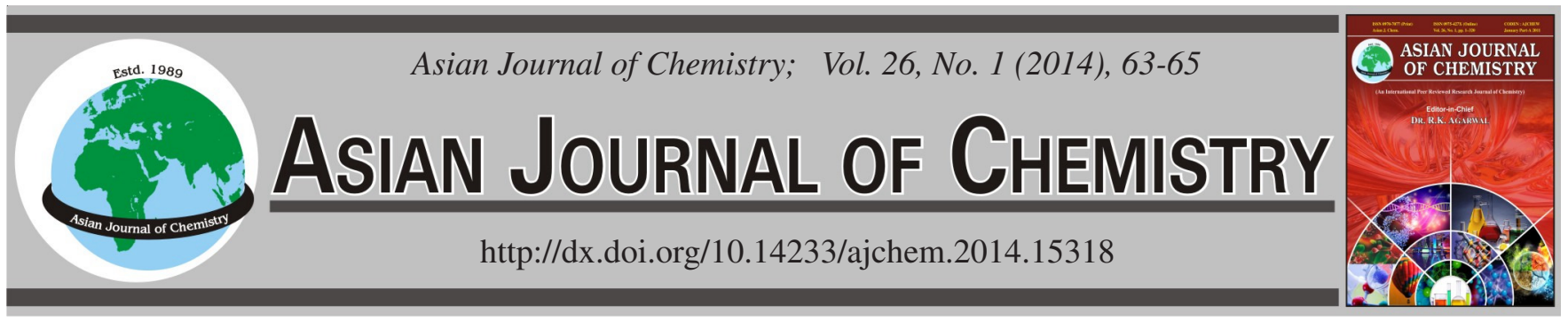

\title{
Effect of Magnetic Field on the Rate of Production of Cadmium Powder from Cadmium Solutions by Cementation of Zinc
}

\author{
S.F. ABAZA ${ }^{1}$ and A.M. AHMED ${ }^{2, *}$
}

${ }^{1}$ Department of Physics, Faculty of Science, King Abdulaziz University, Jeddah 22254, Saudi Arabia

${ }^{2}$ Department of Chemistry, Faculty of Science, Alexandria University, P.O. 426, Ibrahimia, Alexandria 21321, Egypt

*Corresponding author: E-mail: profabdelmonem@gmail.com

Received: 13 February 2013;

Accepted: 19 July 2013;

Published online: 26 December 2013;

AJC-14474

The effect of magnetic field on the rate of cementation of cadmium from cadmium sulphate on zinc was studied. Variables studied were
cadmium sulphate concentration and magnetic field intensity. It was found that the rate of cadmium cementation increases significantly with
increasing the intensity of magnetic field. The percentage of increase in the rate of cementation ranges from 9.2 to $125 \%$. Results were
explained on the basis that the application of magnetic field produces magneto hydrodynamic flow which enhances the rate of cementation.

Keywords: Cementation of zinc, Cadmium, Mass transfer, Magnetic field.

\section{INTRODUCTION}

Cementation is one of the most effective and economic techniques for recovering toxic and/or valuable metals from industrial waste solution. Cementation is used as a general term to describe the process whereby a metal is precipitated from a solution of its salts by another electropositive metal by spontaneous electrochemical reduction to its elemental metallic state, with consequent oxidation of a sacrificial metal. The process has been largely used in industry for a long time, not only in hydrometallurgy but also in the purification process of wastewaters ${ }^{1-8}$.

The cementation reactions are considered as heterogeneous processes limited by diffusion through the mass boundary layer. The rate of cementation not only depend on the prevailing hydrodynamic conditions but also depends on the nature of the deposited metal, powdery non coherent deposits may enhance the rate of cementation while smooth coherent deposit may inhibit the rate of cementation.

Mechanistic studies of cementation reactions have revealed that cementation is electrochemical in nature which takes place through a galvanic cell ${ }^{9-11}$. For the present case where $\mathrm{Cd}$ ions are cemented on $\mathrm{Zn}$, the galvanic cell is: $\mathrm{Zn}$ / $\mathrm{CdSO}_{4} / \mathrm{Cd}$, the cell reactions are:

$$
\begin{array}{ll}
\text { Anode: } \mathrm{Zn} \rightleftharpoons \mathrm{Zn}^{2+}+2 \mathrm{e}^{-} & \mathrm{E}_{\mathrm{o}}=-0.7618 \mathrm{~V} \\
\text { Cathode: } \mathrm{Cd}^{2+}+2 \mathrm{e}^{-} \rightleftharpoons \mathrm{Cd} & \mathrm{E}_{\mathrm{o}}=-0.4030 \mathrm{~V}
\end{array}
$$

$\mathrm{E}_{\mathrm{o}}$ is the standard cell potential where:

$$
\mathrm{E}_{\mathrm{o}}=\mathrm{e}_{\mathrm{o}-\mathrm{ve}}+\mathrm{e}_{\mathrm{o}+\mathrm{ve}}=0.7630 \mathrm{~V}-0.4030 \mathrm{~V}=0.2570 \mathrm{~V}
$$

The extent to which $\mathrm{Cd}^{2+}$ can be removed by cementation on $\mathrm{Zn}$ can be determined from the equation:

$$
\Delta \mathrm{G}_{\mathrm{o}}=-\mathrm{RT} \ln \mathrm{K}
$$

where: $\Delta \mathrm{G}_{\mathrm{o}}$ is the standard free energy of the cell reaction:

$$
\mathrm{Zn}+\mathrm{Cd}^{2+}=\mathrm{Zn}^{2+}+\mathrm{Cd}
$$

$\mathrm{K}$ is the equilibrium constant of the reaction

$$
\mathrm{K}=\frac{\left[\mathrm{Zn}^{2+}\right]}{\left[\mathrm{Cd}^{2+}\right]}
$$

so,

therefore

$$
\begin{gathered}
\Delta \mathrm{G}_{\mathrm{o}}=-\mathrm{ZE}_{\mathrm{o}} \mathrm{F}=48.250 \mathrm{~kJ} \mathrm{~mol}^{-1} \\
\Delta \mathrm{G}_{\mathrm{o}}=-\mathrm{RT} \ln \mathrm{K} \\
\mathrm{K}=3.511 \times 10^{17}
\end{gathered}
$$

The high value of the equilibrium constant $\mathrm{K}$ shows that cementation of $\mathrm{Cu}^{2+}$ by $\mathrm{Zn}$ can lower $\mathrm{Cu}^{2+}$ concentration in waste solution below the maximum permissible value. The removal of heavy metals especially $\mathrm{Cu}^{2+}$ by cementation has been studied by a number of researchers who used different less noble metals such as $\mathrm{Zn}, \mathrm{Fe}$ and $\mathrm{Al}$ and different methods to enhance the rate of cementation such as the rotating disc ${ }^{12,13}$, the rotating cylinder ${ }^{14}$, agitated vessels ${ }^{15}$, gas sparging ${ }^{16}$, fixed and uidized beds ${ }^{17}$ and surface pulsation ${ }^{1}$. In most of the cases the cementation reactions from dilute solutions have been found to follow rst-order diffusion controlled kinetics ${ }^{18,19}$.

The aim of this work is to investigate an effect of magnetic field on the rate of cementation of $\mathrm{Cd}^{2+}$ on $\mathrm{Zn}$.

\section{EXPERIMENTAL}

The apparatus showed in Fig. 1 consists of $250 \mathrm{~mL}$ glass beaker containing $200 \mathrm{~mL}$ cadmium sulphate solution in which 


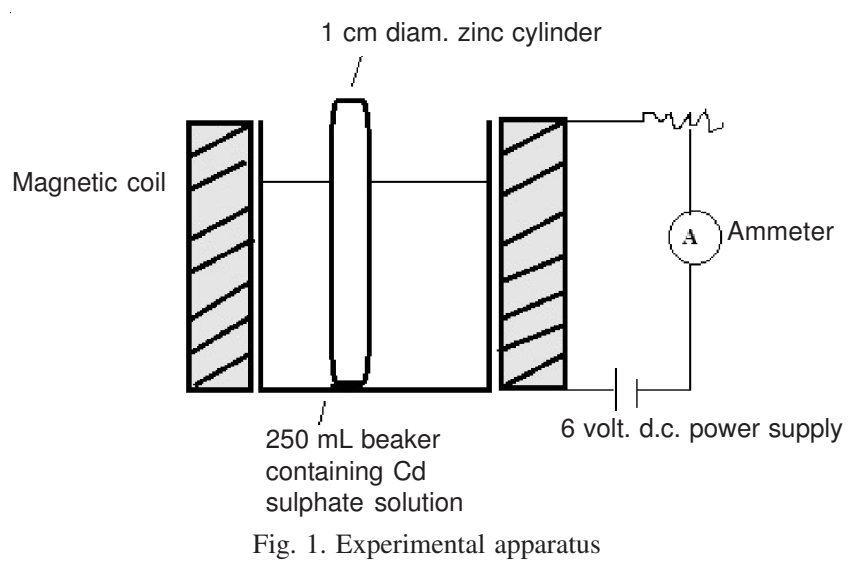

a zinc cylinder of $1 \mathrm{~cm}$ diameter and $7 \mathrm{~cm}$ height is immersed. The glass beaker was surrounded by a magnetic coil connected in series with 6 volt d.c power supply, a rheostat and a multirange ammeter. The strength of magnetic field was varied by changing the current passing through the circuit.

The magnetic flux density was calculated from the current passing through the circuit using the equation:

$$
\mathrm{B}=\mu_{\mathrm{o}} \mathrm{n}_{\mathrm{o}} \mathrm{I}
$$

where $B$ is the magnetic flux density in tesla, $\mu_{0}$ is the magnetic permeability constant $\left(4 \pi \times 10^{-7}\right.$ Weber/amp. $\left.\mathrm{m}\right), \mathrm{n}_{\mathrm{o}}$ is the number of turns per unit length and $I$ is the current passing through the circuit in amperes.

The rate of cementation of cadmium on zinc was determined by analyzing the residual cadmium solution after 80 min of cementation. Cadmium solution was analyzed using EDTA titration ${ }^{20}$.

Each experiment was carried out twice using a fresh solution and a fresh zinc cylinder. All chemicals were of A.R grade, all solution was prepared using distilled water. Temperature was $23 \pm 1{ }^{\circ} \mathrm{C}$ during all experiments. Before each run the flat end of zinc cylinder was isolated with epoxy resin.

\section{RESULTS AND DISCUSSION}

The cementation reaction is diffusion controlled reaction whose rate in a bath reactor can be represented by equation ${ }^{21}$ :

$$
\begin{gathered}
\mathrm{Cd}^{2+}+\mathrm{Zn}=\mathrm{Cd}+\mathrm{Zn}^{2+} \\
-\mathrm{V}\left(\frac{\mathrm{dc}}{\mathrm{dt}}\right)=\mathrm{KAC}
\end{gathered}
$$

which integrated to

$$
\mathrm{V} \ln \left(\frac{\mathrm{C}_{0}}{\mathrm{C}}\right)=\mathrm{KAt}
$$

where $\mathrm{V}$ is the volume of solution containing $\mathrm{Cd}^{2+}, \mathrm{C}_{\mathrm{o}}$ is the initial concentration $\mathrm{Cd}^{2+} ; \mathrm{C}$ is the concentration of $\mathrm{Cd}^{2+}$ at a time $\mathrm{t} ; \mathrm{K}$ is the mass transfer coefficient; $\mathrm{t}$ is the time of cementation.

Eqn. 11 was used to calculate the mass transfer coefficient of cadmium cementation on zinc under different conditions. Fig. 2 give the relation between $\log \mathrm{C}_{\mathrm{o}} / \mathrm{C}$ and time for different concentration of $\mathrm{Cd}^{2+}$ at $25{ }^{\circ} \mathrm{C}$ before used magnetic field intensity. Table-1 gives the values of mass transfer coefficient in present of magnetic field intensity.

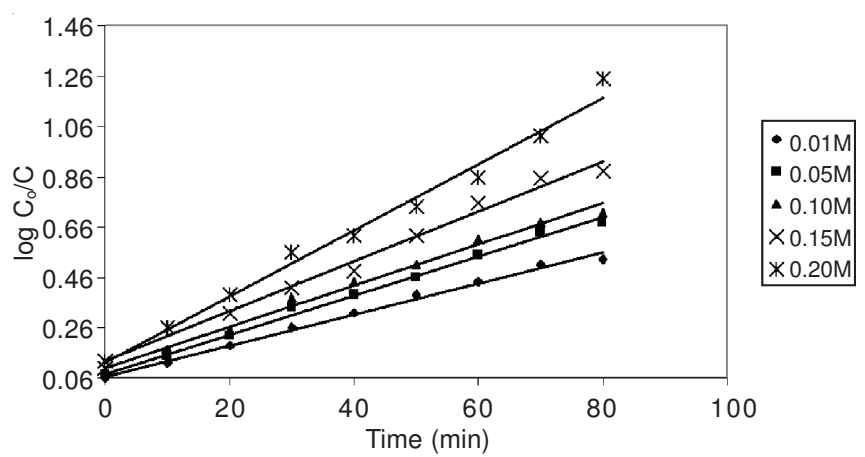

Fig. 2. Relation between $\log \mathrm{C}_{\mathrm{o}} / \mathrm{C}$ against time (min) at $25^{\circ} \mathrm{C}$ using different concentration of $\mathrm{Cd}^{2+}$

TABLE-1

VALUES OF RATE OF MASS TRANSFER COEFFICIENT AT DIFFERENT MAGNETIC FIELD INTENSITY AT DIFFERENT CdSO ${ }_{4}$ CONCENTRATION AT $25^{\circ} \mathrm{C}$

\begin{tabular}{cccccc}
\hline & \multicolumn{5}{c}{$\mathrm{CdSO}_{4}\left(\mathrm{~mol} \mathrm{~L}^{-1}\right)$} \\
\cline { 2 - 6 } $\begin{array}{c}\text { Magnetic field } \\
\text { intensity tesla } \\
10^{4}(\mathrm{~B})\end{array}$ & $0.01 \mathrm{M}$ & $0.05 \mathrm{M}$ & $\begin{array}{c}0.075 \\
\mathrm{M}\end{array}$ & $0.10 \mathrm{M}$ & $0.15 \mathrm{M}$ \\
\cline { 2 - 6 } & \multicolumn{5}{c}{$\mathrm{K} \times 10^{3}$} \\
0.00 & 2.495 & 2.993 & 3.263 & 3.553 & 4.028 \\
2.25 & 2.725 & 3.263 & 3.608 & 4.208 & 4.290 \\
4.50 & 2.995 & 3.580 & 3.992 & 4.375 & 5.650 \\
6.75 & 3.570 & 3.915 & 4.510 & 4.875 & 6.100 \\
9.00 & 3.992 & 4.530 & 5.260 & 5.688 & 6.890 \\
11.50 & 4.720 & 5.430 & 5.960 & 6.495 & 7.720 \\
13.50 & 5.561 & 6.271 & 7.330 & 8.513 & 9.360 \\
\hline
\end{tabular}

Fig. 3 shows the effect of magnetic field intensity on the mass transfer coefficient of cadmium cementation on zinc. For all cadmium concentrations the mass transfer coefficient increase linearly with the magnetic field intensity, the data can be represented by equation:

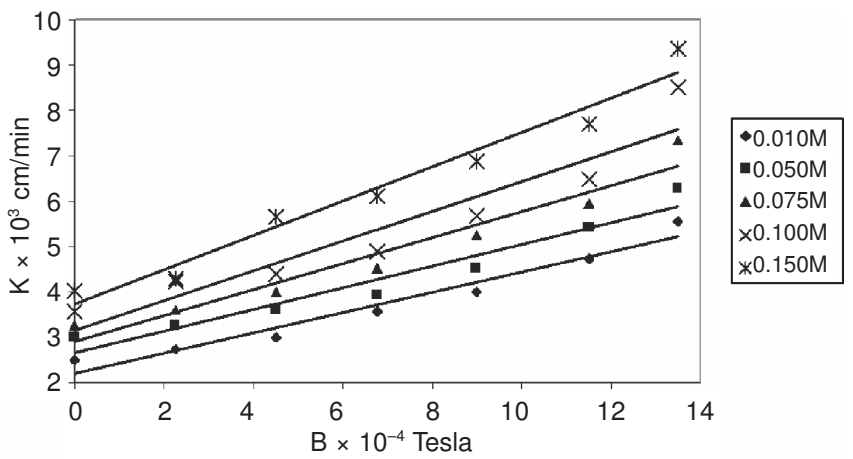

Fig. 3. Effect of magnetic field intensity on mass transfer coefficient

$$
\mathrm{K}=\mathrm{a}+\mathrm{bB}
$$

where $\mathrm{a}, \mathrm{b}$ are constants depending on $\mathrm{Cd}^{2+}$ concentration. Table- 2 and Fig. 4 show that the $\%$ increase in the rate of cementation in presence of magnetic field ranges from 9.2 to $125 \%$.

The increase in the rate of cementation in the presence of magnetic field can be explained as follows:

As a result of deposition of cadmium on the zinc surface the solution in the immediate vicinity of the zinc surface becomes less concentrated in cadmium ions than the bulk solution. This difference in concentration gives rise to the formation 
TABLE-2

EFFECT OF MAGNETIC FIELD INTENSITY ARE THE \% INCREASE IN THE RATE OF CEMENTATION AT

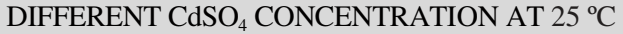

\begin{tabular}{cccccc}
\hline \multirow{2}{*}{$\begin{array}{c}\text { Magnetic field } \\
\text { intensity tesla } \\
10^{4}(\mathrm{~B})\end{array}$} & $0.01 \mathrm{M}$ & $0.05 \mathrm{M}$ & $0.075 \mathrm{M}$ & $0.10 \mathrm{M}$ & $0.15 \mathrm{M}$ \\
\cline { 2 - 6 } & \multicolumn{5}{c}{ Acceleration $(\%)$} \\
\hline 2.25 & 9.20 & 9.50 & 12.12 & 20.00 & 32.50 \\
4.50 & 20.00 & 20.00 & 22.60 & 25.00 & 41.20 \\
6.75 & 44.00 & 44.00 & 38.00 & 38.00 & 50.00 \\
9.00 & 60.00 & 64.00 & 61.14 & 63.14 & 72.30 \\
11.50 & 92.00 & 80.00 & 84.30 & 85.00 & 92.30 \\
13.50 & 117.70 & 109.00 & 121.00 & 123.60 & 125.00 \\
\hline
\end{tabular}

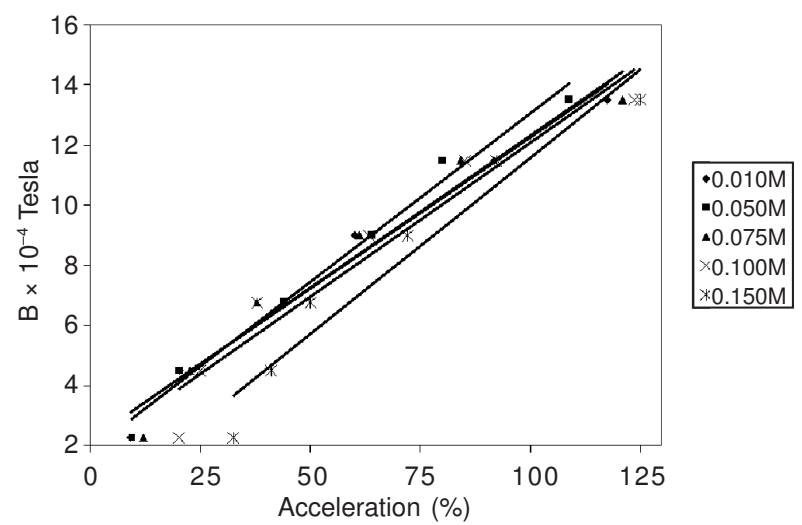

Fig. 4. Effect of magnetic field intensity on the $\%$ increase in the rate of cementation at different $\mathrm{CdSO}_{4}$ concentration at $25^{\circ} \mathrm{C}$

of a diffusion layer at the zinc cylinder across which cadmium ions diffuse from the bulk solution to the zinc surface to sustain the cementation reaction.

In the presence of magnetic field, solution flow takes place at the zinc surface by virtue of Lorentz's force ${ }^{22,23}$.

This force exists as a result of the interaction between the magnetic field and the electrical field which is established at the zinc surface due to the formation of the following galvanic cell through which cementation takes place:

$$
\mathrm{Zn}\left|\mathrm{Zn}^{2+}\right| \mathrm{Cd}^{2+} \mid \mathrm{Cd}
$$

Solution flow at the zinc surface induced by Lorentz's force increases the rate of transfer of cadmium ions to the zinc surface and enhances the rate of cementation. Solution flow may further enhance the rate of cementation if the cadmium deposit is highly rough. According to Ibl et al. ${ }^{24}$ when a fluid flows past a roughness element, eddy formation takes place in the wake of the roughness element with a consequent increase in degree of stirring and rate of cementation. The interaction between surface roughness resulting from the deposition of cadmium powder on the zinc surface and the induced flow is likely to take place when the particle size grows sufficiently and extends beyond the diffusion layer i.e., this effect does not exist in the early stages of cementation.

The present finding that magnetic field application enhances the rate of cementation is consistent with the finding of previous authors who studied the effect of magnetic field on the rate of electrodeposition of metals. Fahidy et al..$^{25,26}$ found that the limiting current of copper electrodeposition increases with increasing the intensity of magnetic field. Cousins et al..$^{27}$ found that magnetic field application increases the current efficiency of chromium electrodeposition.

In area of corrosion, Ghabashy et al. ${ }^{28,29}$ reported an increase in the rate of corrosion under the influence of magnetic field.

\section{Conclusion}

The increase in the rate of cementation causes by magnetic field effects as revealed by the present work underline the importance of magnetic field as a competitive tool for enhancing the rate of diffusion controlled processes. However, before recommending the use of magnetic field in practice, a study should be conducted on a pilot pant scale to assess the economic feasibility of using magnetic field as a tool for enhancing the rate of diffusion controlled processes in comparison to other methods such as mechanical stirring.

\section{REFERENCES}

1. A.A. Mubarak, A.H. El-Shazly and A.H. Konsowa, Desalination, 167, 127 (2004).

2. T. Agelidis, K. Fytianos and G. Vasilikiotis, Chemosphere, 14, 1001 (1985).

3. P.H. Strickland and F. Lawson, In eds.: D.J. Evans and R.S. Shoemaker, The Measurement and Interpretation of Cementation Rate Data, Proceeding of the International Symposium of Hydrometallurgy, AIME, New York, p. 293 (1973).

4. L. Makhloufi, B. Saidani and H. Hammache, Water Res., 34, 2517 (2000).

5. A.K. Biswas and W.G. Davenport, Extractive Metallurgy of Copper, Pergamon Press, Oxford, edn. 2 (1980).

6. J.P. Gould, M.Y. Masingale and M. Miller, Water Pollut. Control Fed., 3, 280 (1984).

7. K.J. Hedrickson, M.M. Benjamin, J.F. Ferguson and L. Goebel, J. Water Pollut. Control Fed., 5, 468 (1984).

8. D.J. MacKinnon, T.R. Ingraham and R. Kerby, Can. Metall. Quart., 10, 165 (1971).

9. G.P. Power and I.M. Richie, Metal Displacement Reactions in Modern Aspects of Electrochemistry, Plenum Press, N.Y., Vol. 11 (1975).

10. G. Rossi, Biohydrometallurgy, McGraw Hill, Hamburg, Germany (1990).

11. A.K. Biswas and W.G. Davenport, Extractive Metallurgy of Copper, Pergamon Press, N.Y. (1979).

12. P.H. Srickland and F. Lawson, Pros. Aust. Inst. Min. Met., 236, 25 (1970).

13. D.J. Mackinnon and T.R. Ingraham, Can. Met. Quart., 9, 443 (1970).

14. A.K. Biswas and J.G. Reid, Pros. Aust. Inst. Min. Met., 242, 37 (1972).

15. S.A. Nosier, Chem. Biochem. Eng. Q, 17, 219 (2003).

16. S.A. Noseir, Alexandria Eng. J., 35, 39 (1996).

17. Y.A. El-Taweel, Z. Met. kd., 79, 544 (1988).

18. R.D. Agarwal, J. Mines, Metals Fuels, 36, 138 (1988).

19. A.H. Konsowa, Desalination, 254, 29 (2010).

20. Vogel's Text Book of Quantitative Inorganic Analysis, Longman Group Ltd., edn. 4 (1978).

21. P.H. Strickland and F. Lawson, Proc. Australas. Inst. Min. Metall., 1, 249 (1973).

22. T.Z. Fahidy, J. Appl. Electrochem., 13, 553 (1983).

23. E.J. Kelly, J. Electrochem. Soc., 124, 987 (1977).

24. N. Ibl, P. Delahary and C.W. Tobias, Adv. Electrochem. Electrochem. Eng., 2, 49 (1962).

25. S. Mohanta and T.Z. Fahidy, Can. J. Chem. Eng., 50, 248 (1972).

26. O. Wassef and T.Z. Fahidy, Electrochim. Acta, 21, 727 (1976).

27. C.A. Cousins, J. Dash and C. Gorg, J. Appl. Phys., 55, 2606 (1984).

28. M.A. Ghabashy, G.H. Sedahmed and I.A.S. Mansour, Corros. J., 17, 36 (1982).

29. M.A. Ghabashy and M. Fawzy, J. Electrochem. Soc., 132, 94C (1985). 